ル内面と夜体との摩擦抵抗が大きい場合柱ノズル長さの 增大による流速の增加はガラスノズルの場合に比してか 故り小さい，熔鉄と耐火物ノズルとの場合はさらに複襍 な要因方入つてくるものと考えられるが，これらについ てはなお今後の研究に待たなけれはななない。

\section{IV. 結 言}

水銀や水を使用し $10 \mathrm{~mm} \phi$ ノズルにてその流出性能 を調査した結果はつぎのとおりである。

（i）全開時における流出，jet の安定性尚上するた 办入側にテーパーをつけ，また法平行直線部を短かく したノズルはストッパー微開時に捣いても普通ノズルに 沘してその流出性能を低下するようなことはない。

(ii）使用中揢鋼による侵虽などのためノズル出口側
径を増加するがまたはストッパー閉鎖時の圧力による 変形のためノズル入口側径が縮小寸る場合ははげしい乱 流となり悪影響が大きい。

(iii) ノズルより流出した jet が鋳型内にすでにだ つている液体内部に巻き込む深さは落下距蜼や，ズル入 口側 headよりもノズル径により左右される.流出条件 が悪く乱流となるような場合はノズル径の大なるほどそ の悪影響は大きい。

(iv) ノズル内面摩擦抵抗の大きい場合は小さい場合 に比して流出状況は若干劣るようである。 また摩擦抵抗 の大きい酎火物留ノズルの場合は硝子ノズルの場合に比 してノズル長の增大による流速の増加ががり少ない。

(昭和 33 年 12 月寄稿)

$\mathrm{W}$ 高速度鋼中の炭化物についで

（実用特殊鋼中の炭化物の電解分離による研究一VII）

佐藤知雄**.西沢泰二*** . 村井弘佑***

\title{
On Carbides in Tungsten High Speed Steels.
}

(Study on carbides in commercial special steels by electrolytic isolation-VII)

Tomoo Sato, Dr. Eng., Taiji Nishizawa and Kousuke Murai.

Synopsis:

The carbides isolated electrolytically from two kinds of high speed steels $-18-4-1$ and 114-2-were studied by chemical analysis and $\mathrm{X}$-ray examination. The results obtained are as follows.

(1) The carbides in the annealed structure of these high speed steels are composed of $\mathrm{M}_{6} \mathrm{C}, \mathrm{M}_{28} \mathrm{C}_{6}$ and a little amount of $\mathrm{MC}$, as reported by many investigators.

(2) By austenitizing treatment, $\mathrm{M}_{23} \mathrm{C}_{6}$ completely dissolves into matrix, but most part of $\mathrm{M}_{6} \mathrm{C}$ remains as undissolved carbides. By the same treatment, $\mathrm{MC}$ in $18-4-1$ steel is dissolved completely, but in the case of 11-4-2 steel, a part of it remains.

(3) The chemical composition of the matrix of these steels quenched from $1250^{\circ} \mathrm{C}$ are very similar as follows:

$$
\begin{array}{ll}
18-4-1 ; & 0.5 \% \mathrm{C}, 7 \cdot 4 \% \mathrm{~W}, 4.5 \% \mathrm{Cr}, 0.9 \% \mathrm{~V} \\
11-4-2 ; & 0.6 \% \mathrm{C}, 6.5 \% \mathrm{~W}, 4 \cdot 7 \% \mathrm{Cr}, 1.3 \% \mathrm{~V}
\end{array}
$$

(4) On tempering above $400^{\circ} \mathrm{C}$, cementite appears first, and then $\mathrm{W}_{2} \mathrm{C}$, $\mathrm{MC}$ and $\mathrm{M}_{7} \mathrm{C}_{3}$ transitionally precipitate, and finaly $\mathrm{M}_{6} \mathrm{C}$ and $\mathrm{M}_{23} \mathrm{C}_{6}$ are formed.

(5) The tungsten concentration in precipitated carbides increases gradually with the rise of tempering temperature. But the vanadium concentration in precipitated carbides reaches

* 凅和 32 年 10 月本会講演会にて発表 ** 東北大学工学部教授, 工博

**** 東北大学工学部金属工学科 
to a maximum percentage, and then dicreases with the rise of tempering temperature.: This may result from the fact that the rate of carbide formation of tungsten is slower than that of vanadium, and so the previously formed vanadium carbides are diluted by the later formed tungsten carbides.

\section{I. 緒言}

本研究においては，18-4-1 型高速度鋼（SKH 2) ならびに 11-4-2 型高速度鋼（SKH 6) の炭化物につ いて電解分離法による研究をおこない（1）焼針組織中 の炭化物の組成, 存在量, 結晶型,およびこれと平衡す る地鉄の組成，(2) 焼入のための加熱によるオーステナ イトへの炭化物の溶解状況，(3) 焼㞔により析出する炭 化物の結晶型と組成などを究明することを企てた．実験 試料の化学組成は Table 1 に示すごとくである.

\section{II. 高速度鋼中の炭化物に関する 交献の概観}

高速度鋼中に存在する炭化物に関して従来打こなわれ た研究は膨大な数に上るが，これらの研究の中をBain， Grossmann132) がすでに 1924 年, 18-4-1 型高速度鋼 中の炭化物を塩酸法によつて電解分離し，艺の組成を分 析しておること特筆に值する. Westgren, Phragmen ${ }^{8\rangle}$, Gil14などは 18-4-1 型高速度鋼中の炭化物につ いてX線分析を抗てない，これは $\mathrm{Fe}_{3} \mathrm{~W}_{3} \mathrm{C}$ を主体とし， $\mathrm{Cr}$ ，Vを固溶した複炭化物であるとして，(Fe，W， Cr， V) ${ }_{8} \mathrm{C}$ と即した。 また Grossmann; Bain's, 武田》, 村 上，八田6) らは高速度鋼についての状態园安研究し, $\mathrm{Fe}_{3} \mathrm{~W}_{3} \mathrm{C} ， \theta$ ならびに $\mathrm{Fe}_{3} \mathrm{~W}_{2}$ 专桡成相とした切断状態図 老提出している. その後, Cohen ${ }^{729}$, Goldschmidt ${ }^{10}$ ) らは各種の高速度鋼中の炭化物について広汎な研究をお こない，高速度鋼の焼鈍または焼入組鐡中には（Fe, W， $\mathrm{Cr}, \mathrm{V})_{6} \mathrm{C}$-以下 $\mathrm{M}_{6} \mathrm{C}$ と部す一一他に, $\mathrm{Cr}_{28} \mathrm{C}_{6}$ 之同 一棈造の炭化物 $\mathrm{M}_{28} \mathrm{C}_{3}$ ，ならび视 $\mathrm{V}_{4} \mathrm{C}_{3}$ を主体とする
炭化物 MC 加存在するとと定明らがにした。しかし， これに対して Kuo ${ }^{112}$ は $\mathrm{M}_{6} \mathrm{C}, \mathrm{M}_{23} \mathrm{C}_{6}, \mathrm{MC}$ の他に さらに $\mathrm{Cr}_{7} \mathrm{C}_{8}$ を主体とする炭化物 $\mathrm{M}_{7} \mathrm{C}_{8}$ 名存在重密 報告している.

高速度鍽の狫㞔における炭化物の挙動についても, 二 次硬化現象と關連して多くの研究が括こないれたが,

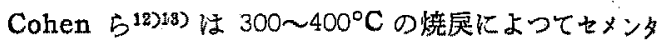

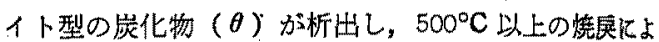
つては特殊炭化物が析出することをX線分析, 磁気分析 蓺膨脹測定などの実験結果から推論した。 また，Goldschmidt ${ }^{10}$ 仕高速度鋼の焼戻組織中の炭化物を電解分離 して，これをX線分析し，二次硬化にさいして析出音 特殊炭化物は $\mathrm{M}_{23} \mathrm{C}_{6}$ と $\mathrm{M}_{6} \mathrm{C}$ との中間の組成定有安名 結晶型の不明な遷移的炭化物であるとしたが，Kuo"恃 この邆移的炭化物蛙 $\mathrm{Mo}_{8} \mathrm{C}$ ，同じ結晶型の $\mathrm{W}_{2} \mathrm{C}$ で ると報告している。

\section{III. 実験結果ならびに考察}

（1）焼鈍組繊中の炭化物ならびに地鉄の組成 各試料を䊁鈍 $\left(900^{\circ} \mathrm{C}\right.$ に 時間加熱後, 1 時間圽 $20^{\circ} \mathrm{C}$ の割合で俆冷)した組織中から電解分離によつて得られ た炭化物の量（琹量\%）之，その化学分析ならびにX線 分析結果，および地鉄の化学組成の計算結果をTable 2 に示す。

焼鈍組織中の炭化物は従来の研究1) -109 亿よつて明与 かにされたと同稼に，大部分が $\mathrm{M}_{6} \mathrm{C}$ 型炭化物であり， これに付随して $\mathrm{MC}$ 型炭化物戈よひ $\mathrm{M}_{23} \mathrm{C}_{6}$ 型宸化籍 に相当する回折線がわずかに認められた。な和前記のよ

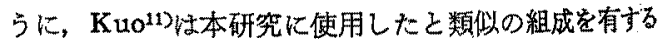

Table 1. Chemical composition of specimens.

\begin{tabular}{c|c|c|c|c|c|c|c|c}
\hline \hline Steel & C & Si & Mn & P & S & W & Cr & V \\
\hline 18-4-1 (S K H 2) & 0.73 & 0.20 & 0.41 & 0.026 & 0.027 & 18.58 & $4 \cdot 17$ & 1.00 \\
$11-4-2$ (S KH 6) & 0.86 & 0.22 & 0.41 & 0.018 & 0.025 & 11.02 & $4 \cdot 42$ & 1.97 \\
\hline
\end{tabular}

Table 2. Metallographic analysis of carbide and ferrite in the annealed specimens.

\begin{tabular}{|c|c|c|c|c|c|c|c|c|c|c|}
\hline \multirow{2}{*}{ Steel } & \multirow{2}{*}{$\begin{array}{l}\text { Amount of } \\
\text { carbide (wt } \%)\end{array}$} & \multirow{2}{*}{$\begin{array}{l}\mathrm{X} \text {-ray patterns } \\
\text { of carbide }\end{array}$} & \multicolumn{4}{|c|}{$\begin{array}{c}\text { Composition of carbide } \\
(\%)\end{array}$} & \multicolumn{4}{|c|}{$\begin{array}{c}\text { Composition of ferrite } \\
(\%)\end{array}$} \\
\hline & & & $\langle\mathrm{C}\rangle$ & $><W$ & $<\mathrm{C}$ & $\langle\mathrm{V}\rangle$ & {$[\mathrm{C}]$} & [W] & {$[\mathrm{Cr}]$} & [V] \\
\hline $\begin{array}{l}8-4-1(\text { S K H } 2) \\
1-4-2(\text { S K H } 6)\end{array}$ & $\begin{array}{l}27 \cdot 0 \\
19 \cdot 7\end{array}$ & $\begin{array}{l}\mathrm{M}_{8} \mathrm{C}+\mathrm{M}_{23} \mathrm{C}_{6} \\
\mathrm{M}_{6} \mathrm{C}+\mathrm{M}_{28} \mathrm{C}_{6}\end{array}$ & $\begin{array}{l}2 \cdot 7 \\
4 \cdot 3\end{array}$ & $\begin{array}{l}61 \cdot 4 \\
53 \cdot 6\end{array}$ & $\begin{array}{r}7 \cdot 1 \\
10 \cdot 4\end{array}$ & $\begin{array}{l}3 \cdot 4 \\
9 \cdot 1\end{array}$ & $\overline{-}$ & $\begin{array}{l}2 \cdot 1 \\
0 \div 8\end{array}$ & $\begin{array}{l}3 \cdot 1 \\
3 \cdot 0\end{array}$ & $\begin{array}{l}0 * 1 \\
0 * 2\end{array}$ \\
\hline
\end{tabular}


18-4-1、型および 11-4-2 型高速度鋼の焼鈍組織 $\left(700^{\circ} \mathrm{C}\right.$ $k 500$ 時間焼戻) 中に $\mathrm{M}_{7} \mathrm{C}_{3}$ 型炭化物の存在すること を報告しているが，本研究ならびにW堸中の炭化物に関 する研究やの結果を総括乙て考察すると，高速度銅の焼 錐組織中に $\mathrm{M}_{7} \mathrm{C}_{3}$ 型炭化物放存在方方可能性はほとえ ど皆無と思われる.しかし，後述するごとく，高速度鋼 の焼戻組織中には遷移相の一つとして $\mathrm{M}_{7} \mathrm{C}_{3}$ 型炭化物 の出現することが認められた。

（2）焼入組織中の未溶解炭化物の量と組成，ならび に基質の組成

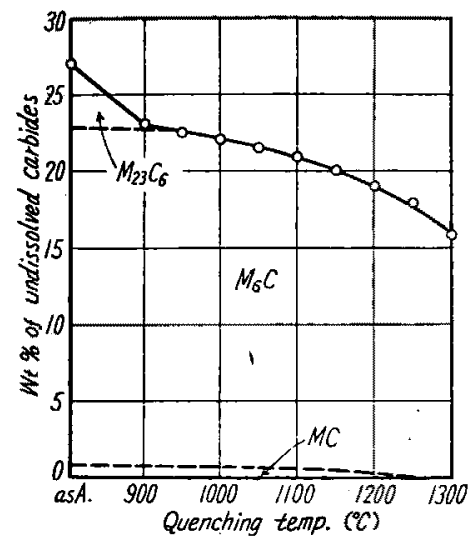

Fig. 1. Weight percentage of different carbides in the quenched 18-4-1 steel.

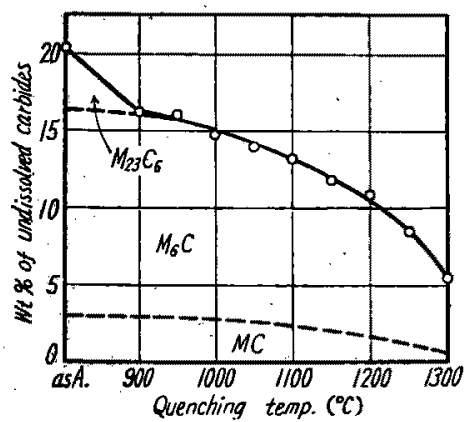

Fig. 2. Weight percentage of different carbides in the quenched 11-4-2 steel.

Fig.1および Fig.2 はそれぞれ 18-4-1 型および 11-4-2 型高速度銅の焼入組織中の未 溶解炭化物の総量 $\left(\mathrm{M}_{8} \mathrm{C}+\mathrm{MC}+\mathrm{M}_{2 \mathrm{~B}} \mathrm{C}_{3}\right)$ 广らびに各炭化物の存在量の推 定值を重量\%にて図示したものである゙。两図に明らか：

*一般に，二璉類以上の宸化物が組織中に介在する場 合に，各炭化物の量比正確に決定することは困難 であるが，本研究に打いては，炭化物の $\mathrm{X}$ 線分析な らびに化学分析值を総合して，各炭化物の量比を推 定した。詳細は次報に部述する。
なごとく， $\mathrm{M}_{23} \mathrm{C}_{8}$ はオーステナイトに溶解しやすく， 変態点直上の温度に加熱することによつて，はとえど完 全に溶解するに対して, $\mathbf{M}_{6} \mathrm{C}$ はオーステナイトに溶解し 難く，その大部分方来溶解炭化物乙して残存す万》〜10)。 なお，MCも元来オースデナトに溶解し難い炭化物で あるといわれているが7ー10)，18-4-1 鋼の場合に $1250^{\circ} \mathrm{C}$ 付近の焼入のた の加熱によつて完全に溶解し終つて括 るのは，18-4-1 鋼にては MC.の含有量が,オーステ ナイトに対する MC の固溶限よりも少ないことによる と解釈される.

上記したような各炭化物のオーステナイトへの溶解度 の差異は，㜔入組織中の未溶解炭化物の化学組成之烧入 温度との関係曲線にもらかがわれる。すなわち，Fig. 3 および Fig. 4 は両鋼定種種なる温度から焼入れた場合
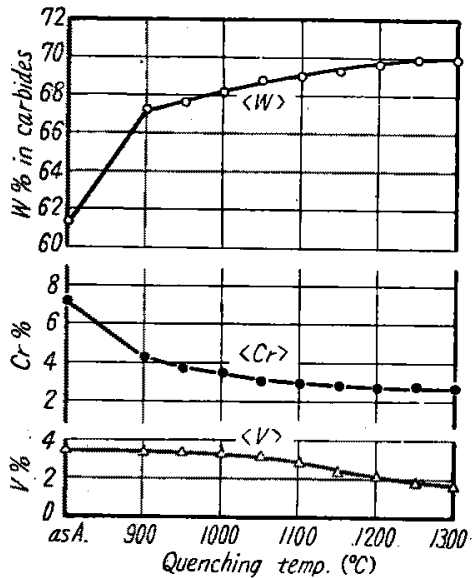

Fig. 3. $\mathrm{W}, \mathrm{Cr}$ and $\mathrm{V}$ concentration in carbides in the quenched 18-4-1. steel.
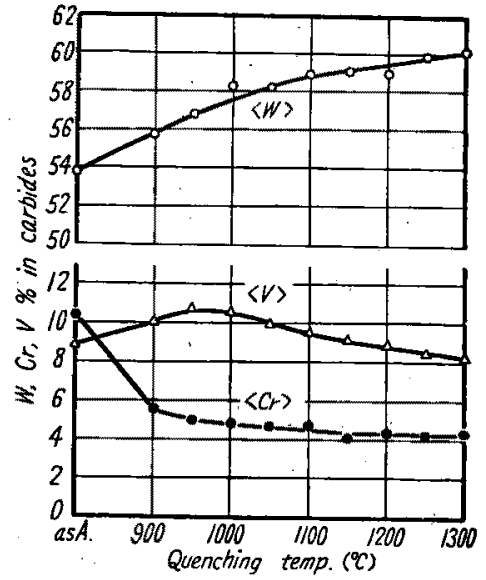

Fig. 4. $\mathrm{W}, \mathrm{Cr}$ and concentration in the carbides in the quenched 11-4-2 steel. 
に存在する未溶解炭化物の $\mathrm{W}, \mathrm{Cr}, \mathrm{V}$ 濃度の分析值を示 したものであるか， $900^{\circ} \mathrm{C}$ から焼入れた場合の未溶解炭 化物の Cr 摆度が，烛鈍状態のものに比して急減してお ることは， $\mathrm{Cr}_{\mathrm{r}}$ 含有量の大なる $\mathrm{M}_{23} \mathrm{C}_{6}$ がオーステナイ ト中に固溶したことを意味する。また末溶解炭化物のW 湄度は烧入温度の上昇に伴なつて增加しているが，これ はW含有量の大なる $\mathrm{M}_{6} \mathrm{C}$ がオーステナイトに溶け込み 蜼いために，未溶解炭化物中にお污る $\mathrm{M}_{8} \mathrm{C}$ の㓶合が増 加したことを意昧するものと解积される。

末溶解炭化物の量とその化学組成についての以上の実 験結果をもとにして，オーステナイトの $\mathrm{C}, \mathrm{W}, \mathrm{Cr}, \mathrm{V} の$ 固溶量を算出すれば Fig. 5 および Fig. 6 のごとくで ある。

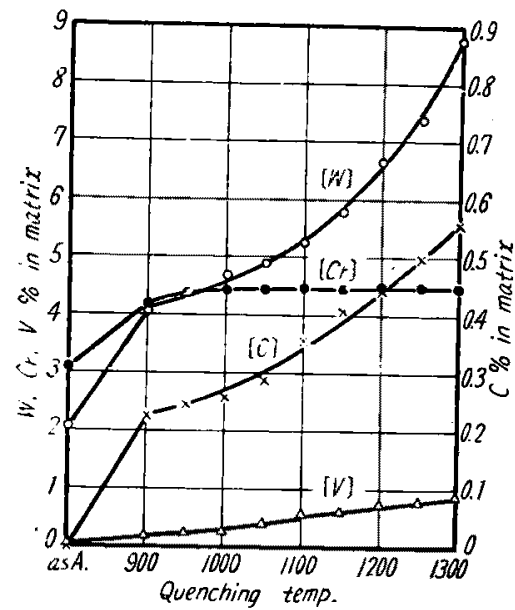

Fig. 5. C, W, $\mathrm{Cr}$ and $\mathrm{V}$ concentration in matrix in the quenched 18-4-1 steel.

实た，実用の焼入温度 $\left(1250^{\circ} \mathrm{C}\right)$ における未溶解炭 化物の量, 結晶型, 組成，ならびにこれと共存するオー
ステナイトの組成を Table 3 に一括して表示した

（3）焼㞔により析出する炭化物

すでに前報15316引においても記したように，高速度算中 ダイス鋼のごとく焼入組織中に未溶解炭化物の球存千゙ 鋼では，これを焼戻したのち電解すると，㜔民にるる析 出炭化物之未溶解炭化物とが全く混合した状態で抽出さ れるから，析出炭化物自体の本性を追究することか国数

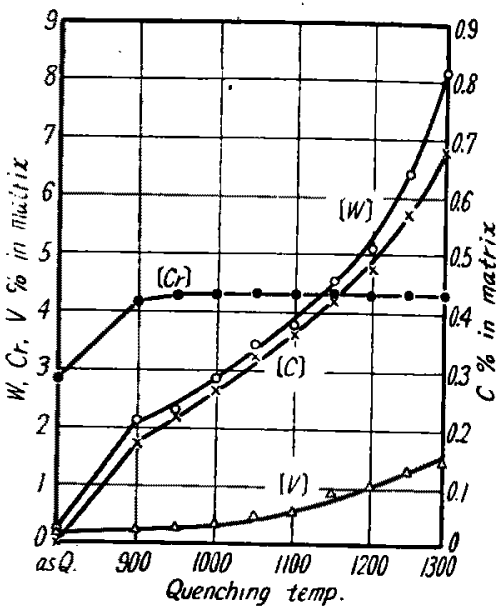

Fig. 6. C, W, $\mathrm{Cr}$ and $\mathrm{V}$ concentration in matrix in the quenched 11-4-2 steel.

である.したがつて，焼戻による析出炭化物の挙動を宽 明するためには，焼入組織中の基質と同一の組成老有し これを焼入れた場合に未溶解炭化物の存在しないような 銅が必要である．これを基地鋼と称することにする。 以 下の焼戻穾験においては，Table 4に示したようか 184-1 型高速度鋼の焼入基質（Table 3参照）に類饮の柤 成を有する基地鋼（SKH 2-M）を熔製して試料とし， 焼戾による析出炭化物の組成および結晶型を研究した。

Fig.7 および Fig.8 はこの基地銅 (SKH2-M)

Table 3. Metallographic analysis of carbides and matrix in the specimens, quenched from $1250^{\circ} \mathrm{C}$.

\begin{tabular}{|c|c|c|c|c|c|c|c|c|c|c|}
\hline \multirow{2}{*}{ Steel } & \multirow{2}{*}{$\begin{array}{l}\text { Amount of } \\
\text { carbide (wt \%) }\end{array}$} & \multirow{2}{*}{$\begin{array}{l}\text { X-ray patterns } \\
\text { of carbide }\end{array}$} & \multicolumn{4}{|c|}{$\begin{array}{c}\text { Composition of carbide } \\
(\%)\end{array}$} & \multicolumn{4}{|c|}{$\begin{array}{c}\text { Composition of ferrite } \\
(\%)\end{array}$} \\
\hline & & & $\langle\mathrm{C}\rangle$ & $\langle w\rangle$ & $\angle \mathrm{Cr}$ & $\langle\mathrm{V}\rangle$ & {$[\mathrm{C}]$} & {$[\mathrm{W}]$} & {$[\mathrm{Cr}]$} & [V] \\
\hline $\begin{array}{l}18-4-1(\text { S K H } 2) \\
1-4-2(\text { S K H } 6)\end{array}$ & $\begin{array}{r}16 \cdot 9 \\
8 \cdot 5\end{array}$ & $\begin{array}{c}\mathrm{M}_{6} \mathrm{C} \\
\mathrm{M}_{6} \mathrm{C}+\mathrm{MC}\end{array}$ & $\begin{array}{l}1 \cdot 9 \\
3 \cdot 9\end{array}$ & $\begin{array}{l}69 \cdot 8 \\
60 \cdot 0\end{array}$ & $\begin{array}{l}2 \cdot 7 \\
4 \cdot 3\end{array}$ & $\begin{array}{l}1 \cdot 9 \\
8 \cdot 5\end{array}$ & $\begin{array}{l}0.5 \\
0.6\end{array}$ & $\begin{array}{l}7 \cdot 4 \\
6 \cdot 5\end{array}$ & $\begin{array}{l}4 \cdot 5 \\
4 \cdot 7\end{array}$ & $\begin{array}{l}0.9 \\
1.3\end{array}$ \\
\hline
\end{tabular}

Table 4. Chemical composition of matrix steel, which is prepared as similar to the matrix of $18-4-1$ steel quenched from $1250^{\circ} \mathrm{C}$.

\begin{tabular}{c|c|c|c|c|c|c|c|c|c}
\hline M. Steel & C & Si & Mn & P & S & W & Cr & V \\
\hline S K H 2-M & 0.48 & 0.28 & 0.37 & 0.028 & 0.024 & $8 \cdot 36$ & $4 \cdot 57$ & $1 \cdot 15$ \\
\hline
\end{tabular}




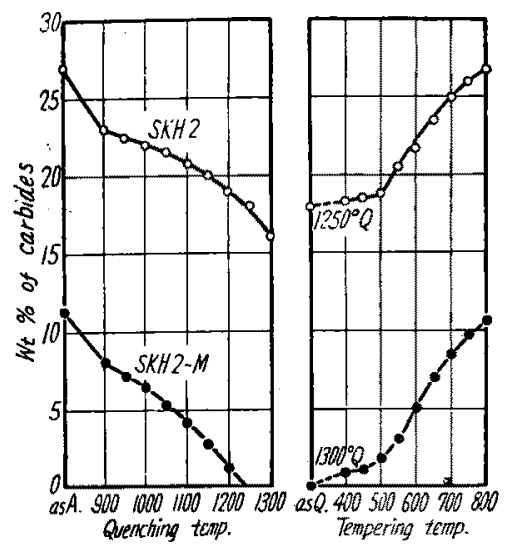

Fig. 7. Weight percentage of carbides in the quenched, and in the tempered matrix steel (SKH2-M), compared with those of 18-4-1 steel (SKH 2).

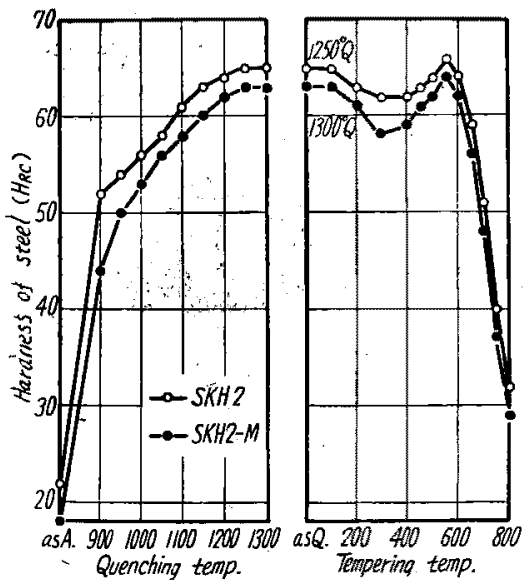

Fig. 8. Hardness of the quenched, and the tempered matrix steel (SKH2-M), compared with those of $18-4-1$ steel (SKH 2).

$900 \sim 1300^{\circ} \mathrm{C}$ の各温度から焼入れた場合，ならびに 1300 ${ }^{\circ} \mathrm{C}$ から焼入れた後 $800^{\circ} \mathrm{C}$ までの各温度に 1 時間焼厌し た場合の炭化物量（重量\%) と硬化 (HRC) を18-4-1鋼 (SKH 2) のそれらと比較して示したものである.

两図に明らかなごとく，基地鋼中の病化物量は，末溶 解质化物に相当する量だけ少ないが，焼入，焼送に伴な

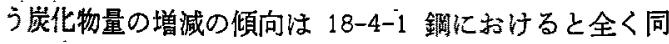
棣である.また，基地鋼の焼入ならびに焙戻硬度の変化 性常に 18-4-1 鋼とほとんど同様の傾向定示す.ただし 18-4-1 銅は未溶解炭化物量の多いだけ硬度が若干高い。

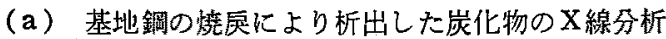
結果

Table 5 は基地鋼の焺戻組織中から分攡した炭化物の $\mathrm{Cr}-\mathrm{K} \alpha$ 線によるX線分析の結果であつて，450年およ び $500^{\circ} \mathrm{C}$ の焼质組織中の炭化物はせメンタイト型の結 晶構造を有与る $\theta$ 炭化物であるが， $650^{\circ} \mathrm{C}$ 以上の炾㞔維 織では， $\mathrm{W}_{2} \mathrm{C}$ (穴方晶)， $\mathrm{MC}$ (立方晶)， $\mathrm{M}_{6} \mathrm{C}$ (立方晶)， $\mathrm{M}_{7} \mathrm{C}_{3}$ (三方晶)， $\mathrm{M}_{23} \mathrm{C}_{6}$ (立方晶)の回折線が認められた。 しかし，二次硬化のもつともいらじるしい $550^{\circ} \mathrm{C} な$ びに $600^{\circ} \mathrm{C}$ における焼戻組䅧中から分離した炭化物は きわ微細であるために，回折線を得ることができな

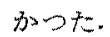

Table 5. X-ray anatysis of carbides isolated from tempered matrix steel.

\begin{tabular}{|c|c|}
\hline Tempering temp. $(\times 1 \mathrm{~h})$ & Carbide phases \\
\hline $\begin{array}{l}450^{\circ} \mathrm{C} \\
500^{\prime \prime} \\
550 \prime \prime \\
600^{\prime \prime} \\
650 \prime \prime \\
700^{\prime \prime} \\
750^{\prime \prime} \\
800^{\prime \prime}\end{array}$ & $\begin{array}{c}\theta \\
\theta \\
* \\
\mathrm{~W}_{2} \mathrm{C}+\mathrm{MC} \\
\mathrm{W}_{2} \mathrm{C}+\mathrm{MC}+\mathrm{M}_{3} \mathrm{C}_{8} \\
\mathrm{M}_{6} \mathrm{C}+\mathrm{MC}+\mathrm{M}_{7} \mathrm{C}_{3} \\
\mathrm{M}_{6} \mathrm{C}+\mathrm{MC}+\mathrm{M}_{28} \mathrm{C}_{6}\end{array}$ \\
\hline
\end{tabular}

* no refiection lines were detected.

以上のX線分析の結果から，焼戻における炭化物の析 出過程についてつぎのごとく考察される. 寸なるち,

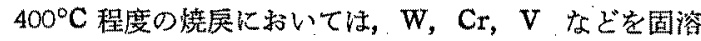
したセメンタイト( $\theta$ 炭化物) 方形成されるが, $500^{\circ} \mathrm{C}$ 以上の焼戻（焼戾の第四段階）においては，W， Cr， V などの原子が易動性を得て，それぞれの元素に特有の炭 化物总形成しはじ，これに伴なつてセメンタイトは消 失する.この場合，各特殊元素が最初に形成する崖化物 は，かならずしも最終安定系における炭化物之同一では なく，(1）Wはまず $W_{2} \mathrm{C}$ 觉形成してのち $\mathrm{M}_{6} \mathrm{C}$ に邆移

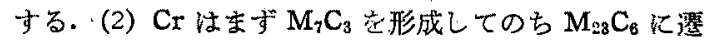
移する：しかし，（3）Vの形成する初期炭化物は最樂炭 化物と同様に MC であると考える。

（b）基地鋼の焼庆により析出した炭化物の化学分析 結果

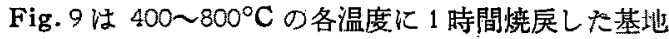

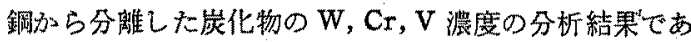
る.

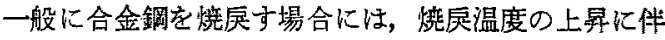
なつて，炭素に対する漞和力の大なる特殊元素は炭化物 に濃集するのが通則であるしかるに，Fig.9に示した 炭化物の分析結果においては，炭化物中のV濃度は 650 


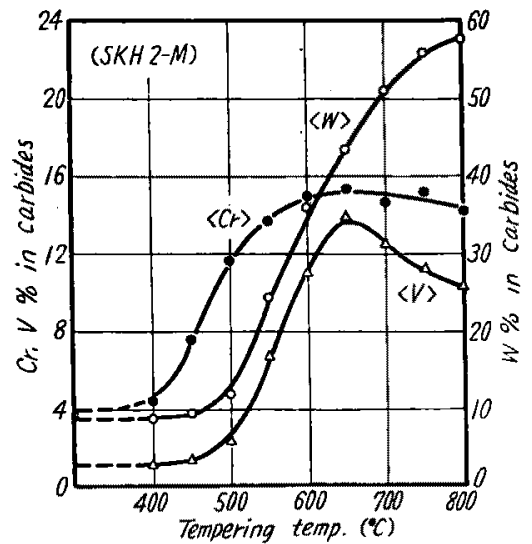

Fig. 9. $\mathrm{W}, \mathrm{Cr}$ and $\mathrm{V}$ concentrations in carbides, isolated from the matrix steel (SKH2-M), tempered at various temperatures for $1 \mathrm{~h}$.

○○の焼戻において最高值に達し，これ以上の温度では むしろ低減している。この理由は，前報17にも述べたご とく，Wの易動性がVのそれより小なることによるので あつて, $650^{\circ} \mathrm{C}$ の焼戻によつてVはMC型炭化物の形成 をほぼ完了するのに対し，W方炭化物形成する速度は きわめて遅く, $650^{\circ} \mathrm{C}$ 以上の㜔戻によつて徐徐に $\mathrm{W}_{2} \mathrm{C}$ 䛢よび $\mathrm{M}_{6} \mathrm{C}$ を形成するために，さきに析出したMC型 炭化物の全炭化物量に対する割合が低減し，結局，炭化 物中のV濃度が見掛上減少するのであると考えられる。

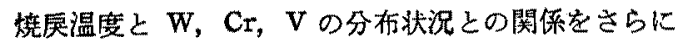
明確にするために，炭化物に結合した $\mathrm{W} ， \mathrm{Cr} ， \mathrm{~V}$ の割 合（析出炭化物量 $\times$ 特殊元素濃度 $/ 100 \times$ 鋼の特殊元素含 有量）を計算した 絬果を示せば Fig.10 のごとくであ

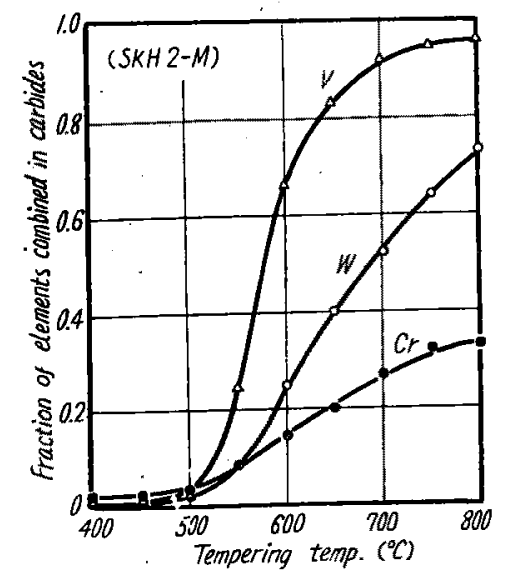

Fig. 10. Fraction of elements combined in carbides in the tempered matrix steel (SKH2-M).
つて，各元素ともに，焼戻温度の上昇に伴なつて凯化 に結合する割合は增加しており，この中で方がるる すみやかに笼化物を構成するに対して，Wはきかめて荤

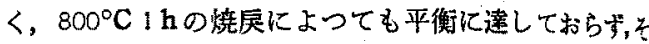

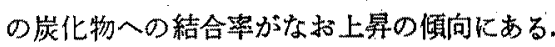

\section{IV. 総括}

18-4-1 型高速度鐝（SKH 2）ならびに 11-4-2 型高 速度銅（SKH 6)の炭化物について電解分離法による形 究をおこない，つきの結果を得た.

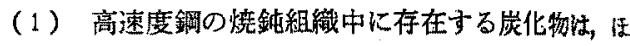
とえどが $\mathrm{M}_{6} \mathrm{C}$ (Wを主体とする炭化物) であり，て虬 に付随して $\mathrm{M}_{23} \mathrm{C}_{6}$ ( $\mathrm{Cr}$ を多量に含有する炭化物) 小. び MC（V妾主体とする炭化物）が出現する.

（2）㜔入にさいして $\mathrm{M}_{23} \mathrm{C}_{6}$ はオーステナイトに滰 解しやすいが， $\mathbf{M}_{6} \mathbf{C}$ はオーステナイトに溶解し嚾く，

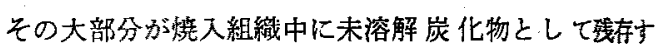

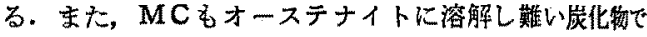
あるが，18-4-1 型においては，焼鈍組織中に存在才寺 MCの絶噇が少ないために，焼入のための加熱にさい して完全にオーステナィトに溶解する.

（3）焼入温度が $1250^{\circ} \mathrm{C}$ の場合の $\mathrm{SKH} 2$ 和计 SKH 6 の基質の組成は，大略つぎのごとくであり，き わめて類似している。

SKH2-M; $0.5 \% \mathrm{C}, 7.4 \% \mathrm{~W}, 4.5 \% \mathrm{Cr}, 0.9 \% \mathrm{~V}$

SKH6-M; $0.6 \% \mathrm{C}, 6.5 \% \mathrm{~W}, 4.7 \% \mathrm{Cr}, 1.3 \% \mathrm{~V}$ SKH2-M を基準とした組成の鋼を熔製し；これを基姲 龬と称した。

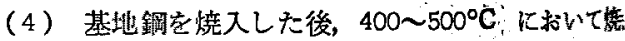
扊した場合，析出する炭化物は $\theta$ 宸化物である。 $500^{\circ} \mathrm{C}$ 以上の焼戻では特殊元素が易動性を得て，そかとれれ元

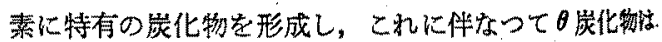
消失する.

各特殊元素の炭化物形成の過程はつぎのでとくで る.

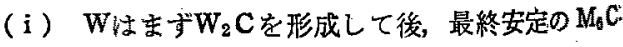
を到成京る。

(ii) $\mathrm{Cr}$ はまず $\mathrm{M}_{7} \mathrm{C}_{3}$ を形成して後 $\mathrm{M}_{28} \mathrm{C}_{6}$ に通接 する。

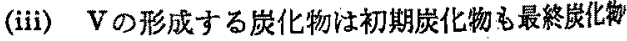
もとむにMCである。

（5） $500^{\circ} \mathrm{C}$ 以上の焼戻における各特殊炭化物の惯 速度を比较すると，Vが MC を形成する速度防する も速く，W が $\mathrm{W}_{2} \mathrm{C}$ および $\mathrm{M}_{\mathrm{B}} \mathrm{C}$ を形成する速度加る。 
つと荤い。

終的に臨み，本研究遂行上御助力いただいた東北大学 工学部助教授金子秀夫博士，ならびに日産自動車株式会 社澺水敏佐氏亿感謝与る。

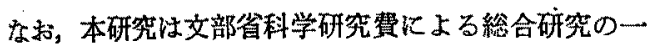
部であることを付記する（昭和 33 年 10 月寄稿）

$$
\text { 文献 }
$$

1) E. C. Bain, M. A. Grossmann, J.I.S.I., 110 (1924), 249

2) M. A. Grossmann, E. C. Bain, High Speed Steel, (1931), 169

3) A. Westgren, G. Phragmen, A.S.S.T., 13 (1928), 539

4) J. P. Gill, A.S.M., 24 (1936); 735

5) 武田：金属の研究，6 (1929), 509

6）村上，八田：龬，21 (1935)，993

z) D. J. Blickwede, M. Cohen, J. Metals, 1
(1949), 578

8) D. J. Blickwede, M. Cohen, G. A. Roberts, A.S.M., 42 (1950), 1161

9) F. Kayser, M. Cohen, Metal Progress, 61 (1952), 79

10) H. J. Goldschmidt, J.I.S.I., 170 (1952), 189

11) K. Kuo, J.I.S.I., 174 (1953), 223

12) M. Cohen, P. K. Koh, A.S.M., 27 (1939), 1015

13) B. S. Lement, M. Cohen, A.S.M., 30 (1942) 1021

14）佐藤，西沢，大橋：日本金属学会誌，21 (1957), 662

15）佐藤，本田，西沢：鉄と鎆，42(1956)，1118

16）佐藤，西沢，村井：鉄と鋼，44（1958），565

17）佐藤，西沢，村井：鉄と鋼飞投稿中

18）小柴，木村：铁と銅，44（1958）, No. 3,9,

\title{
純 鉄 の衝 撃引張”試 験”
}

作 井誠 太亦大森 正 信***

\section{Behavior of Pure Iron under Impact Tensile Loading.}

\author{
Seita Sakui,' Dr. Eng., and Masanobu Omori.
}

Synopsis:

The behavior of pure iron under impact tensile loading was studied with two kinds of pure Irons and a commercial low carbon steel. One half of specimens were annealed in vacuum at $600,700,800,850,920$ and $1000^{\circ} \mathrm{C}$ for 1 hour and the others were quenched in oil after keeping them at these temperatures for 1 hour in vacuum.

At the impact tensile test, in which the specimen was loaded by the hammer, falling by gravity and weighing $25 \mathrm{~kg}$, the load acting on the specimen was measured by the use of piezoelectricity of quartz crystals and the cathode ray oscillograph. X-direction of the oscillograph was fed by piezoelectricity, $\mathrm{Y}$-axis corresponded to time axis There was no electronic circuit between quartz and a deflection plate of the oscillograph and the load-time curve was directly recorded on the film inside the oscillograph. The strain rates at the impact tests were appToximately $20 \sim 1201 / \mathrm{sec}$

The results obtained in this investigation were as follows.

(1) The peak appeared in the load-time curve under impact test seemed to be upper yield point:

(2) Yield stress and tensile strength were larger and total elongation was smaller than those under static test.

(3) Increasing the strain rate, both yield stress and tensile strength increased and total elongation decreased slightly. The rate of increase of yield stress was greater than that of tensile strength.

* 昭和 33 年 10 月本会講演大会で発表 ** 東京工業大学教授 工搏 *** 東京工業大学 工修 